Gabriela Spanghero Lotta' ${ }^{1}$, Giordano Morangueira Magri' (D), Ana Carolina Nunes ${ }^{1}\left(\mathbb{D}\right.$, Beatriz Soares Benedito ${ }^{2}$, Claudio Aliberti ${ }^{1}$ (D) , Erika Caracho Ribeiro ${ }^{3}$ (D), Fernanda Lima Silva' ${ }^{1 D}$, Gabriela Thomazinho' ${ }^{(1 D}$,

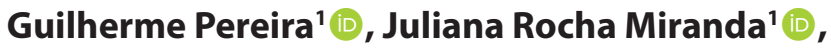
Marcela Garcia Corrêa' ${ }^{1}$, Mariana Costa Silveira' ${ }^{1}$, Morgana G. Martins Krieger ${ }^{1}$ (D) , Taciana Barcellos ${ }^{4}$ (D) \& Alexsandro Santos ${ }^{1,5}$ (D)

\title{
The impact of the Covid-19 pandemic on the performance of street level bureaucrats in Brazil ${ }^{6}$
}

\section{Introduction}

Crises, like the one produced by the COVID-19 pandemic, present serious challenges for public administration, in Brazil and worldwide. Coping with the pandemic impacts requires the implementation of diverse public policies prioritizing the reduction of deaths and infections and the mitigation of various social and economic effects. Such policies depend on the performance of frontline professionals who, through daily contact with the population, perform emergency public services (DUNLOP et al., 2020).

For over four decades, the literature on these professionals - usually referred to as street-level bureaucrats (SLBs) - demonstrates how, even during periods of normality, their work is characterized 
by pressure, indecision and suffering (LIPSKY, 2010), but also by vocation and heroism (MAYNARD-MOODY; MUSHENO, 2003). In street-level work, professionals tend to exercise a high degree of discretion, as rules are generally comprehensive and require interpretation and adaptation to real cases (FERNANDEZ; GUIMARÃES, 2020; LOTTA, 2019). Furthermore, the literature argues that this kind of work is marked by excessive workloads and scarce resources (LIPSKY, 2010), putting SLBs in a key position to decide who receives what and how much (VAN OORSCHOT, 2006).

In times of crisis, these conditions tend to become even more critical. We understand crises as long periods of threat and extreme uncertainty that disrupt social, political and organizational systems and processes (BOIN; 'T HART, 2003). At such times, conditions become more extreme, firstly, because the crisis exacerbates problems of scarce resources, excess demand, unpredictability and the need for rapid decision-making (DUNLOP et al., 2020). Secondly, crises increase ambiguity, make the limits of existing regulations and previous experience for dealing with new scenarios more explicit, thus increasing both uncertainty and the discretion that SLBs wield (ALCADIPANI et al., 2020; HENDERSON, 2014; MATLAND, 1995). Finally, crises increase the suffering faced by SLBs, particularly to those professionals who have to deal with death, and the feelings of risk due to the exposure to disease and difficult working conditions. As such, while coping with the COVID-19 crisis requires intensive activity by SLBs, it also creates a critical situation that impacts their work, aggravating or altering the conditions already identified in the literature (ALCADIPANI $e t$ al., 2020; DUNLOP et al., 2020).

Considering this context, this article aims to understand the effects of the pandemic on the everyday activities of SLBs in Brazil in different policy sectors. In selecting sectors to research, we sought to prioritize both policy areas that are strategic for tackling the pandemic, such as health and social assistance, and also those that have been heavily impacted by the new dynamics of social interaction but are not directly related to fighting the disease, such 
as education, public security and free legal assistance. Although these different areas have their own particular work dynamics, since many are embedded in their own policy systems, such as the Sistema Unico de Saúde (Unified Health System, SUS) and the Sistema Unico de Assistência Social (Unified Social Assistance System, SUAS) for example, the challenges for all frontline services are similar at this moment of crisis (GOFEN; LOTTA, 2021)

Methodologically, this article is based on exploratory analyses of data collected by a research group seeking to understand the implications of the new working dynamics of SLBs in Brazil during the COVID-19 pandemic. Between March and August 2020, data on different policies were collected through interviews, documentary analysis of legal changes, and surveys and virtual debates with managers and frontline professionals from the different sectors studied.

The analysis led us to identify three categories of SLBs operating in the pandemic: (i) those working directly in the response to the crisis; (ii) those who continued to work in person, but in roles unrelated to the COVID-19 response; and (iii) professionals who had started to work remotely, but continued to deliver services directly to the public. The analyses suggest that these professionals are experiencing different dynamics during the pandemic. In general, three key factors influenced the way SLBs exercised their everyday functions during the crisis: (i) processes of centralizing decision-making; (ii) higher levels of ambiguity, that is, uncertainties that permeated the practices of formulating and implementing public policies; and (iii) a greater degree of political conflict over possible courses of action in responding to the pandemic, which has compromised response times and coordination. These factors undermine the ability of frontline workers to act effectively in the provision of quality public services (TAVARES; SILVEIRA; PAES-SOUSA, 2020).

In addition to this introduction and the final considerations, this article is structured in four sections. The second section introduces the concept of street level bureaucracy. The third presents the 
methods of data collection and analysis used. The fourth section analyzes and discusses the results, exploring different types of impacts on SLBs. Finally, the fifth section discusses how the street-level bureaucracy has influenced the implementation of public policies during the COVID-19 pandemic in Brazil and points to conflicts and ambiguities of this process.

\section{Street level bureaucracy: from routine to emergency}

Street-level bureaucracy (SLB) consists of professionals who work on the front lines of public services and implement public policies in the everyday interaction with users (LIPSKY, 2010). Typical examples of SLB are teachers, police, social workers and health professionals. Other SLB professionals who interact directly with the public include prison officers, public defenders and public service administrative workers. The contemporary literature considers that frontline professionals can be considered to be street-level bureaucrats (SLBs) regardless of their employment status or type of contract, since it is their position as a service provider in direct interaction with the user that places them within the SLB category (LIPSKY, 2010).

Through everyday interactions, street-level bureaucracy turns general policy guidelines into allocative decisions that lead to concrete services for the public (BRODKIN, 2012). This process operates based on the discretion of these professionals, that is, on the degree of freedom they enjoy to interpret the rules and make decisions (LOTTA; SANTIAGO, 2017). The more ambiguous and conflictual the policies are, the greater the discretion of the SLB (MATLAND, 1995).

More than four decades of scholarship on SLB have demonstrated that these professionals face challenging working conditions (LIPSKY, 2010): excess demand and scarcity of resources; unpredictable work situations, as they depend on uncontrolled interactions; pressures imposed both by the service managers - who demand productivity - and by the users with whom they interact - who seek attention, personal engagement and optimization of services 
(FERNANDEZ; GUIMARÃES, 2020; LOTTA, 2019; PIRES, 2009; TUMMERS et al., 2015).

It is in this context that SLB needs to make quick decisions which can have major repercussions - such as deciding which patients receive hospital treatment or who meets the requirements to receive a welfare payment. Although, as a vocation based on an ideal of heroism, SLBs see themselves as helping the public (MAYNARD-MOODY; MUSHENO, 2012), it is also a kind of work marked by suffering, alienation and demotivation (LIPSKY, 2010; TUMMERS et al., 2015). To deal with suffering, these professionals develop coping strategies that range from the rationalization of services, to the total protection of the service user at the expense of meeting production targets (TUMMERS, 2017; TUMMERS et al., 2015).

Despite important theoretical developments in the SLB literature, studies generally tend to analyze cases in which routine activities, stable policies and moments of normality prevail. Few studies have explored how these professionals deal with emergencies (HENDERSON, 2014), in which conditions are aggravated in the ways previously described (DUNLOP et al., 2020). Emergencies increase unpredictability; intensify demand and resource scarcity; and, due to reduced regulation and lack of accumulated experience to assist in confronting the situation, enhance the sense of uncertainty (DUNLOP et al., 2020). Such sequences of unexpected and unpredictable events, which we call crises, disturb pre-existing routines, processes and systems, making the possibility of coordination or centralization even more difficult, if not almost impossible (BOIN; 'T HART, 2003; FARAZMAND, 2007).

An emergency, such as the one caused by the spread of COVID19 , has other consequences for SLB activities. The first is that coping with the pandemic basically depends on the performance of these bureaucrats (GOFEN; LOTTA, 2021) - such as health professionals treating patients; social assistance professionals registering families for the distribution of emergency welfare payments; or security professionals working to ensure isolation measures, among others. The second is the feeling of increased risk and suffering among 
professionals, who find themselves in extreme, even life or death, situations and are directly exposed to infection, intensifying their sense of insecurity (KHANAL et al., 2020). Such feelings can be intensified in contexts of political conflict and lack of inter-agency coordination, as in the Brazilian case (ABRUCIO et al., 2020), resulting in increased uncertainty about how best to simultaneously provide the public with adequate care and ensure the safety of frontline workers.

Analyzing the perceptions of SLBs about their activities during this crisis and its consequences for their work, therefore, is a unique opportunity to understand how these professionals react and feel at critical moments, when conditions are even more challenging than those understood as "normality" (BRODKIN, 2021). It is also a way of understanding a specific, sometimes invisible (DUBOIS, 1999), part of the state, where policies are embodied, and what the consequence of the crisis is for the way state action materializes the challenges, the responses that arise, and the innovations created in the midst of the pandemic.

\section{Methods of data collection and analysis}

This is an exploratory study, in which data collection was based on a combination of methodological strategies, including both qualitative and quantitative data collection. It can therefore be described as exploratory mixed methods research (CRESWELL, 2013). The research was approved by the Ethics Committee on June 29,2020 . The study analyzes SLBs, understood as the professionals acting as the link between the public and the state, across several areas, and whose work is characterized by an intense interaction with users and a high degree of discretion (LIPSKY, 2010). This definition allowed us to analyze the experiences of these professionals and outline a typology about the adaptations made to their activities in the context of the COVID-19 pandemic.

In order to understand these professionals' perceptions about the effects of the pandemic on their work procedures and routines, we triangulated information collected from different sources. 
This triangulation allowed us to contrast information gathered from primary (interviews, questionnaires, discussions in debates/ seminars) and secondary (documentary analysis of Federal Government guidelines with recommendations on adaptations in the work processes of these professionals) data sources.

First, we conducted documentary analysis to understand how the government has reorganized street-level services in the areas of health, social assistance, security and education in the context of COVID-19. We analyzed 26 norms created by the Federal Government between March and August 2020 to identify proposals for adapting these services, both in terms of the adoption of new work protocols and of the redefinition of priorities. Although several of these policies are also regulated at the municipal level, we decided to only analyze national guidelines, given the infeasibility of including all subnational guidelines. Furthermore, we understand that federal regulations guide local regulations, especially in the areas of health and social assistance, in which the federal government acts as system coordinator (ARRETCHE, 2012).

Second, a qualitative survey was conducted based on online debates with professionals from different public services. Between March and August 2020, we organized 17 seminars with SLBs, specialists and professionals from diverse sectors, including health, social assistance, education, public security, housing, public transport, urban maintenance and combating contemporary slave labor. The debates were planned and organized by researchers affiliated with the Núcleo de Estudos da Burocracia (Bureaucracy Research Group) at the Getulio Vargas Foundation (NEB - EAESP FGV). They were recorded and transcribed for later analysis and were widely disseminated. They sought to understand, from the point of view of professionals and specialists, how the pandemic affected the implementation of these public policies. In these meetings, numerous testimonies were collected from workers and activists and the impacts, challenges and consequences of the crisis for SLB were discussed collectively. In total, 65 panelists participated, of which 28 were SLBs and the rest were researchers, members of civil 
society organizations, or legislators. The results of these discussions were published on a high-circulation newspaper blog${ }^{7}$ (Blog Gestão, Política \& Sociedade, in O Estado de São Paulo).

Third, data were collected using online surveys, with a non-random sample. We received responses from 8,108 frontline professionals across the country, 3,594 from the health sector, 1,540 from the police, 1,530 from social assistance, 914 from prison officers and 530 from public defenders. The questionnaires were applied in two different stages: between April and May and between June and July 2020. The responses were voluntary and the links to access the surveys were disseminated via social networks and partnerships with workers' organizations. As the sample design was not probabilistic, the purpose of this data collection was not to generate statistically significant results, but rather to develop a dynamic exploratory analysis of the reality faced by these professionals. Such convenience samples are commonly used in organizational studies (BRYMAN, 2016).

The surveys contained questions common to all SLBs, but also included specificities that varied by sector. The general section was divided into issues relating to: (i) feelings of risk; (ii) material and institutional working conditions; (iii) changes in work routines; (iv) articulation with other services; and (v) personal emotions and contact with the public during the period of coping with the crisis. For each topic, changes were made to adapt questions to the context of each profession. The questions were phrased in terms of the SLB literature and exploratory studies on the effects of the COVID-19 pandemic on the wellbeing and working dynamics of public service professionals (DE FELICE et al., 2020; LAI et al., 2020). The questionnaires were reviewed by peers and groups of professionals and question types included nominal qualitative variables (previously established list of options), dichotomous (Yes or No), and open.

Our final data collection strategy involved conducting interviews with representatives of some sectors (presidents of trade unions in 
the areas of public security, social assistance and health) to understand how these institutions have guided their staff and made strategic demands on government for dealing with the pandemic. In total, eight interviews were conducted, lasting approximately 30 minutes each, by telephone or video conference. The interviews followed a semi-structured script, based on the categories drawn from the results of the surveys and documentary analysis. The interviews were transcribed and analyzed alongside the other data.

We produced descriptive statistics from the results of the closed survey questions. To analyze our qualitative data, we used content analysis to categorize responses and identify patterns in the reports (BARDIN, 1994; SALDAÑA, 2009). These data were analyzed in three rounds. First, we coded the data, identifying themes that would help to answer the following questions: (i) what are SLBs feeling in the crisis?; (ii) how did the crisis change the work of SLBs?; and (iii) how did the changes to the work of SLBs affect the public? Then, we reorganized the data in an attempt to find patterns and trends regarding working conditions and the SLBs' perceptions about changes to their work during the crisis. At the end of this process, we identified three types of dynamic, varying according to the services performed by the different professional categories of SLB during the pandemic.

After analyzing the data collected via each method, we triangulated the information to explore how different sources explained what had happened to SLB during the pandemic. We analyzed the extent to which the propositions in the documents and regulations were reflected in the way professionals actually experienced the pandemic, observing its (non-)alignment with the results of the surveys and interviews. This triangulated information is the basis of the analyses presented below.

\section{Analysis and discussion of results: the effects of the pandemic on the work of SLBs}

The data analysis revealed three distinct groups of SLBs in the context of the pandemic: one formed by SLBs who have directly 
confronted the crisis and its consequences on the front lines; a second, with SLBs who continued to provide face-to-face services during the crisis, but who did not respond to it directly; and a third, with SLBs whose work was drastically altered during the crisis so that they ceased to carry out face-to-face frontline work and migrated to remote working. This separation between groups can be seen in the documentary analysis, which shows how some professional categories were classified as essential during the pandemic (in the health, social assistance and security sectors), while regulations for other professional categories pushed them into remote working. These differences also appeared in our other data. Below, we present each group in detail and the consequences they faced during the crisis.

\section{SLBs who confront the crisis and its consequences in person}

The first group refers to professionals who work in services considered essential for responding to the pandemic or its consequences, who continue to work in person and in daily contact with the public. This group includes a substantial part of those working in the areas of health, social assistance and public security.

Worldwide, SLB has proved crucial during the pandemic, ensuring that the state can respond to the public health crisis and its adverse socioeconomic consequences (DUNLOP et al., 2020). In Brazil, it has gained additional importance due to the social vulnerability faced by a significant part of the population and its dependence on public services (COSTA, 2019). Seeking to guarantee to these people the access to pre-existing policies and to the ones created in response to the pandemic, these SLBs cannot operate under social distancing restrictions and must continue working on the streets and in public facilities. As the activities of these professionals necessarily entails direct contact with citizens and exposure to the risk of infection or transmission of the virus, the pressures and uncertainties that permeate the everyday work of these SLBs are dramatically increased, exacerbating the fragilities already experienced by those working on the frontline (PIRES, 2020). 
This situation has had a series of consequences for the way these SLBs work. The first is an increase in demand for work, a situation especially evident in the health sector. However, it is also the case for social assistance workers, because those most vulnerable to the crisis, such as the homeless population and people with precarious housing, work and income conditions, also require additional care (BENEDITO et al., 2020; KRIEGER et al., 2020; LIMA et al., 2020). Furthermore, considering that social isolation measures directly affect the families of the more than 36 million informal workers in the country (IBGE, 2020), new demands have arisen from those who did not use social assistance services before the crisis. In this situation, professionals in this area become essential for delivering the Basic Emergency Income program (BRASIL, 2020), which received 97 million requests (MAXIMUM, 2020). Demand has also increased for services within the prison system, due to the removal of at-risk groups from frontline work, which has led to increased workloads for those who are still active (LIMA; LOTTA, 2020).

The second consequence is that professionals in this group, and their families, are highly impacted by the risk of infection and illness themselves. An example of this is Brazil's unfortunate position at the top of the world COVID-19 mortality rate among nurses (ARAGÃO, 2020). Furthermore, they can also transmit the disease to the population they serve. This occurs in particular in the prison system, where conditions of overcrowding and poor sanitation already favor high rates of infection and mortality resulting from COVID-19 among both professionals and prisoners (CORTEZ et al., 2020; LIMA; LOTTA, 2020). By the first half of September 2020, 121 deaths and 35,000 infections had officially been confirmed among the prison population, with only $8.34 \%$ having been tested (CEPEDISA; CONECTAS HUMAN RIGHTS, 2020). In addition to the illness itself, these conditions lead to increased fear and mental suffering. In several sectors there was a withdrawal of service professionals from at-risk groups. The data from the June 2020 surveys - with 3,842 participants, including 613 professionals from the prison system, 2,138 from the health sector and 1,091 from 
social assistance - show that, on average, $85.6 \%$ of professionals are afraid of contagion and $76.1 \%$ said their mental health had been affected by the pandemic. Meanwhile, $74.4 \%$ of them knew people who have already fallen ill.

The third consequence of the crisis is the impact on the routines of professionals who feel obliged to create new service protocols and criteria for decision-making, in an effort to guarantee both their safety and the viability of their work. This is the case of primary health care professionals, who, for example, must change the way they carry out home visits. These visits are now conducted either via telephone and WhatsApp or through the "gates" of houses, maintaining physical distance. It is also the case of professionals from care centers, who have changed the procedures for receiving and caring for homeless people and victims of domestic violence. Police officers have had to change procedures of stop and search (ALCADIPANI et al., 2020).

The final consequence is that professionals in this group, due to the nature of their work, face new challenges in operationalizing their tasks. An example is the difficulty in guaranteeing the safe functioning of Núcleos de Convivência para Adultos em Situação de Rua (Living Centers for Homeless Adults), which have become ever more crowded due to increased socioeconomic vulnerability. Another is the difficulty of guaranteeing decent working conditions for prison guards, police and other staff in the prison system, given that the system's existing fragilities (SEQUEIRA; BIONDI; GODOI, 2020) coexist with the high risk of COVID-19 transmission and the impossibility of isolating suspected cases.

It should be said that, such effects have been experienced by SLBs worldwide to different degrees and in different ways. However, the response of the Brazilian state to the pandemic has aggravated these already difficult conditions. The data from the June 2020 survey demonstrated the sense of helplessness felt by these professionals, reinforced by the lack of an institutional response or of information for SLB. The survey indicated that 71\% felt unprepared for the crisis, a feeling exacerbated by a perceived lack of support from across the 
three levels of government: $53 \%$ answered that the municipal government had not supported them, $62 \%$ for the state government, and $78 \%$ for the federal government.

These feelings appear justified when we analyze the regulations (or lack thereof) that could guide new working practices among these SLBs. There was a lag between the increased need to protect professionals imposed by the pandemic and legal recognition of such need. It was only with the Law 14.023 of July 2020 that these professionals were defined as essential workers, obliging the public sector to distribute personal protective equipment (PPE) to them and to adopt protective measures for them. The implementation of these decisions required additional resources. Sector-specific regulations also came late or were insufficiently rigorous. For example, in the health sector, regulations for the reorganization of primary care were not introduced until July. Meanwhile, those aimed at community health workers, for example, were full of ambiguities and conflicts (LOTTA et al., 2020). In general, the regulations had little impact on the practices of the SLBs and were focused on administrative operations at the municipal level and on the regulation of private sector activity.

Beyond the legal sphere, the lack of support is also visible in the failure to provide these professionals with PPE and training to support them in making changes to their work practices during the pandemic. Survey data show that by April, only $36 \%$ of respondents had received PPE and, by July, this number had only risen to $50 \%$. By April, only $21 \%$ had received any training and, by July, the average was still only $24 \%$. Just $15 \%$ declared to have received mental health support.

This context of fragmentation and increased procedural uncertainty has had the effect of increasing SLBs margins of discretion. However, the lack of support and material resources impacts how this discretion can be exercised. On the one hand, it may mean a greater focus on citizens and their needs in order to enhance care and access to rights for the most vulnerable populations, based on principles of vocation and heroism (MAYNARD-MOODY; 
MUSHENO, 2003). On the other hand, it can also imply an extreme rationalization of policy implementation, as observed in the accounts of some public health professionals who claimed that it was necessary to establish criteria and be more selective about who would receive intensive care services in cases of excessive demand.

For the population, the consequence of this context is to increase the structural problems of Brazilian society in the provision of public services like healthcare, social assistance and public security. These effects are felt most by vulnerable groups who depend on these services, such as the very poor (BENEDITO et al., 2020; COSTA et al., 2020; KRIEGER et al., 2020; LIMA et al., 2020), women (NUNES et al., 2020) and the black population (SANTOS et al., 2020).

\section{SLBs who work in person during the crisis, but not directly with combating COVID-19.}

The second group includes SLBs that continue to work in person during the pandemic, but whose work does not involve responding directly to it. Examples include those working in the public transport system, urban street cleaning and combating slave labor. Since these are essential services, these professionals must continue working on the streets. Unlike the first group, they do not face a sharp increase in demand for their services or significant changes to their working procedures. On the other hand, given the interactive nature of their work, they are exposed to risks that need to be minimized.

For this reason, the guarantee of physical protection is crucial, via the provision of PPE, training and reorganization of some practices. Some central decisions should be taken by governments to support these SLBs, going beyond the exercise of individual discretion. For example, how should a bus driver react to passengers without masks? How should street cleaners change their procedures to reduce the risk of infection? How does the risk of infection affect the dynamics of rescue operations for workers in conditions of slave labor? 
Analyzing the Brazilian case, we saw that, as with the first group, these SLBs have not received the necessary attention and protection. In the city of São Paulo, for example, the use of masks on buses was only made mandatory at the end of April (SÃO PAULO, 2020), more than a month after the pandemic began. Meanwhile, up until August, the union of municipal bus drivers recorded 246 cases of infection and 68 deaths from COVID-19 (BAZANI, 2020). In the area of street cleaning, urban waste can be an important source of infection for these workers, who, without access to adequate PPE, can become potential transmitters of the virus to their families and the communities where they live.

Regarding combating of modern slave labor, in the first half of 202045 inspections were carried out by labor inspectors from the Divisão para Erradicação do Trabalho Escravo (Division for the Eradication of Slave Labor, DETRAE), resulting in the rescue of 231 workers from conditions analogous to slavery (KLASSMANN, 2020). For these activities, in the context of the pandemic, the teams needed to organize themselves to avoid infection or transmission. The impacts of the pandemic are visible in two ways: first, in the development of remote planning of on-site inspections; second, in the logistical costs of operations, for example, as teams who previously shared accommodation began to hire individual rooms at costs above what their expenses accounts covered.

\section{SLBs working remotely during the crisis}

The third group of SLBs are those who interacted directly with the public but moved to remote work, such as teachers, lawyers, and frontline staff in district administrative offices, the social security institute and the transportation agency, among other bodies. Part of this group is not directly involved in tackling the pandemic, but their work routines have completely changed. Others, especially legal professionals, are working to minimize the consequences of the pandemic and have the challenge of adapting a central component of SLB work: contact with citizens. Given the impossibility of face-to-face contact, these bureaucrats develop strategies to guarantee 
that their target audiences gain access to rights and public policies. Despite changed routines with remote work, these different bureaucrats are considered in this article to be SLB because they continue to interact directly with the public and to mediate the provision of policies (LIPSKY, 2010) - even if they do this remotely, by phone or virtual channels.

The transition, in the provision of these services, from face-to-face to remote and digital interactions, is not exactly a new issue for public services. However, this change used to take place at different speeds, varying according to the type of service, the resources made available by the state, the political agenda, and existing professional and technical skills. The inconsistency of investment towards this transition took a heavy toll on the Brazilian state. Under pressure, due to the impacts of the pandemic and the need to maintain social distancing, it was, in a short period of time, forced to migrate many services to technology-mediated channels.

During the pandemic, this change became the responsibility of SLB, who had to transform their daily practices of face-to-face services delivered directly to users, to the use of remote interaction tools, in the midst of an emergency and without planning. In this process, they were able to rely on some strategies and solutions proposed by top management, but also needed to make adjustments so that they could work reasonably in each context or even develop new strategies that were not foreseen in the new regulations as formulated. The most obvious case was that of education, a sector in which, in the course of a few weeks, professionals had to adopt remote teaching methodologies without having the necessary knowledge, technology or tools. Our documentary analysis shows this process clearly: the measures for long-distance activities proposed in the regulations in the education sector allowed the emergency adoption of remote teaching and the adaptation of management practices for the emergency context (Provisional Measure 934; Law 13,986; CNE Opinions 5 and 11; Ordinance 1,857 and Law 14,040). Another example is public defenders, who, even though they are 
responsible for representing vulnerable groups, halted most face-to-face interaction.

In these two cases, research shows that professionals were unprepared for these changes. Data collected in April and May by the Instituto Península indicate that $88 \%$ of teachers had never taught classes remotely before the interruption of face-to-face classes; $83.4 \%$ felt completely or mostly unprepared for the change and 55\% said they had not received support or training (INSTITUTO PENÍNSULA, 2020). In the case of public defenders, the July 2020 data from the survey show that $83 \%$ of professionals who are working remotely have not received the necessary equipment. Of these, $24 \%$ do not have this equipment at home and $47 \%$ believe that under these circumstances they are unable to serve the public satisfactorily.

These data suggest that, although the pandemic does not put these SLBs at risk of exposure due to remote working, it generates other impacts related to the difficulty of carrying out activities and interactions with service users - causing the suffering for these professionals and a series of consequences for the affected population. In education, for example, teachers and school managers report that virtual learning platforms and educational programming on state television stations are solutions that reach some, but not all, students and their families. For this reason, they point out that they needed to create alternative strategies to keep educational services functioning. Furthermore, there were consequences for students in areas not central to the services themselves - for example, the absence of school lunches greatly impacts food security for a significant part of the population.

In the case of public defenders, a large proportion of the public served does not have access to electronic devices and, therefore, is unable to communicate remotely with SLBs. This is the case, for example, for the homeless population, prisoners and their families. One of our surveys, carried out in July 2020, with relatives of prisoners, shows that $69.6 \%$ of families had not heard from their imprisoned relatives since the beginning of the pandemic due to the difficulty of accessing information about the situation in each 
prison unit and also due to the difficulty of communication with the public defenders' offices. The pandemic has also aggravated some situations treated by public defenders, such as women who suffer domestic violence and who, often isolated with their own aggressors, are unable to access the service (NUNES et al., 2020), demonstrating how digitization negatively impacts access to justice for the most vulnerable population.

Across the different sectors, the remote provision of public services impacted not only the daily work of SLB, but also intensified social inequalities in access to public policies, due to uneven availability of information technologies across the population (BALBE, 2010; SORJ; GUEDES, 2005). Several studies show how the most vulnerable populations could not access or had difficulty accessing existing public services (that started to be delivered remotely) or policies created in the context of the pandemic, such as the Basic Emergency Income (CRISTÓVAM; SAIKALI; SOUSA, 2020). If public policy implementation processes already tended to reproduce inequalities (PIRES, 2019), in contexts mediated by digital devices and platforms - applications, websites, etc. -, digital exclusion tends to further exacerbate these asymmetries (SORJ; GUEDES, 2005). In addition to the issue of digital exclusion, there are complexities and unforeseen problems that arise from the implementation of policies in contexts of crisis, marked by the ambiguity of regulation and procedural uncertainties.

\section{Discussion: the centralization of decision-making processes, conflicts and ambiguities}

Considering that the SLB is composed of professionals who implement public policies in direct interaction with the public (DUBOIS, 1999) and, therefore, there is always a degree of discretion involved in the effective implementation of public policy, what has changed in the context of crisis? We identified three explanatory factors: (i) the centralization of the decision-making processes and the implementation of public policies characterized by contexts of 
(ii) high ambiguity and (iii) greater political conflict. In this section, we discuss each of these three aspects.

The need for urgent responses resulted in (i) the greater centralization of decision-making, a process that is common in crises (DUNLOP, 2020). Despite the assumption that moments of crisis demand leadership that provides top-down instructions, research shows that management is more effective when conducted via polycentric networks that establish negotiation systems that assist the performance of operational managers (BOIN; 'T HART, 2003). Thus, centralization reduces the applicability of regulations, since they do not match the conditions faced by SLBs in the pandemic, increasing the need to use discretion.

The impacts of the pandemic on different types of SLB show the critical situations that many of these professionals face. We attribute part of this severity to the withdrawal of decision-making autonomy from SLB for how to adapt service provision, as well as the new public policy regulations introduced. In general, when developed, strategies and performance protocols are designed centrally and without listening to frontline professionals. The literature has shown how the role of SLBs as policy entrepreneurs allows for changes that enhance their capacity for action (ARNOLD, 2020; FRISCH AVIRAM; COHEN; BEERI, 2020). In times of crisis, the complex and uncertain scenario poses unprecedented challenges for policy formulation. A sense of urgency, which makes it difficult to conduct consultations and debates with SLBs, concentrates power for developing alternative solutions in the higher echelons of service hierarchies.

A markedly top-down process of producing public policies gives excessive prominence to political decision-makers and high-level bureaucrats, working on the mistaken hypotheses that these agents always have: a) a complete and accurate diagnosis of public problems; b) perfect information about who uses the services, the contexts of implementation and interaction regimes; c) a consistent causal model regarding the results and impacts they intend to achieve; d) all the instruments necessary to ensure the commitment 
of all levels of the bureaucracy in the implementation process, once the political decision has been taken; e) an ability to make the policy understandable and operational for all implementing agents, in order to reduce the need for, or possibility of, discretionary actions (HILL, 2007; MAY; WINTER, 2009; PRESSMAN; WILDAVSKY, 1995).

Despite understanding their local areas, the everyday demands of the population and operational bottlenecks (LAVEE; COHEN, 2019), SLBs were initially placed on standby. By closing the policy formulation process, making it impervious to the issues known and routinely experienced by street-level bureaucrats, the risk of these solutions failing has increased (HENDERSON, 2014). Our analyses suggest that SLBs have suffered the consequences of such a decision-making process. In the cases of health, social assistance, public security and legal aid, the data from the surveys carried out in June show that $71 \%$ claim to only partially understand the strategies and protocols that have been developed and do not feel prepared for dealing with the pandemic; while $64 \%$ say they do not feel supported by government.

Furthermore, in qualitative responses, several professionals identified that the specific characteristics of their territories and service users were ignored in the process of formulating solutions. These findings, together with the lack of material resources discussed above, reveal the impacts of this process in excluding and silencing SLB from playing the mediating role essential to public policy success (BECK; BARTOS; LOTTA, 2020; KRIEGER et al., 2020; LIMA; LOTTA, 2020; SANTOS et al., 2020). International experiences discussed in the literature show the effectiveness of involving SLB in the reformulation of policies at this moment of crisis (BRODKIN, 2021; COX; DICKSON; MARIER, 2021; MØLLER, 2021).

The centralization of decision-making processes has specific consequences for different SLB categories beyond the common aspects already highlighted. In the case of SLBs that continued to deliver in person services in direct response to the crisis, they 
were less able to respond to the pandemic as local specificities were disregarded by senior management, thus aggravating operational bottlenecks. For SLBs who continued to work in person but did not face the crisis directly, the lack of specific regulations during the crisis period has exposed them to risk of infection in the exercise of their activities. For SLBs who moved to remote work, a lack of involvement in decision-making processes also contributed to intensifying their sense of unpreparedness, since challenges in the implementation of new practices of interaction with the public were not properly considered.

The (ii) context of ambiguity is a second factor that has undermined the performance of SLB during the pandemic. Ambiguity refers to the uncertainty that permeates policy design and implementation (MATLAND, 1995).

The Brazilian case clearly demonstrates a high level of ambiguity during the pandemic, partly owing to the unprecedented nature of the situation but also accentuated by the absence of intergovernmental coordination (ABRUCIO et al., 2020; TAVARES; SILVEIRA; PAES-SOUSA, 2020). Although over recent decades the Brazilian state has strengthened its capacity to design integrated and coordinated federative interventions, the crisis has shown that it is not sufficient in the absence of leadership (ABRUCIO et al., 2020). Thus, despite the existence of national public policy systems, such as SUS and SUAS, federative cooperation and collaboration does not happen without deliberate decision-making by public officials, especially when the beliefs, interests and logics of political action conflict with or diverge from these systems.

In the period prior to the pandemic, SLB discretion was guided by clearer protocols and a stronger understanding of possible methods of action, based on customs, recurrent practices and even imitation. These systems, whether defined formally or informally, were disrupted by the crisis (FARAZMAND, 2007), increasing SLB discretion and reducing the guidance provided (DUNLOP et al., 2020; GOFEN; LOTTA, 2021). By "producing dynamics that no 
one can predict or control" (FARAZMAND, 2007, p. 150), the crisis affected the way SLB makes use of discretion.

If the increase in discretion could give SLBs greater freedom of action (DUNLOP, 2020), this did not necessarily translate into greater capacity to use that discretion to adapt policies to new circumstances. In line with international findings on SLB during crises, increased discretion without guidance in a context of ambiguity (marked by fears and risks) can reduce capacity to act (GOFEN; LOTTA, 2021; LOTTA; COELHO; BRAGE, 2020; MØLLER, 2021). In the cases analyzed, many of the methods previously used came to be seen as risky activities. Routine activities could no longer be carried out in the same way, as they might worsen the situation of those citizens that SLBs seek to serve, producing contradictory conditions.

Considering the first SLB category, the more ambiguous context for implementation made it difficult to produce clear protocols that could guide these professionals in adopting specific actions in response to the pandemic. This impaired their ability to act, increasing the risks to themselves and the population served. As for the second group, the greatest ambiguity concerns the lack of regulation and the existence of operational bottlenecks that can harm the quality of services provided and also increase risk of exposure for professionals. In the third category, ambiguity results from a lack of adequate training in the transition to distance working and in the (often unexpected) difficulties experienced in serving the most vulnerable groups. These factors can ultimately lead to a reduction in the effectiveness of services and increase inequalities.

The third factor that alters the work of SLBs in times of crisis is (iii) greater political conflict. Conflict is defined as disputes between actors with different views on public policy (MATLAND, 1995). Boin and 't Hart (2003) and Farazmand (2007) point out that high politicization is one of the elements of modern crises. While there is an expectation that elected government leaders will make decisions that put the safety of the population first, in practice these leaders also take into account the economic and political costs of 
regulations (BOIN; 'T HART, 2003), which may vary considerably according to their electoral bases, interests and values. Thus, SLBs, who regularly operate in organized, integrated and coordinated systems, began to experience this conflict in two ways. On the one hand, they have to deal with the consequences of political conflict, by serving members of the public who hold different ideological positions. On the other hand, working under unclear regulations, SLB themselves can propagate political conflict among the individuals they serve, which can result in a reproduction of inequalities (PIRES, 2019).

Political disputes over possible courses of action and divergent discourses between the President, scientists and governors have generated a scenario characterized by contradictory positions, creating problems for those expected to deliver policies. One of the effects of this is the creation of tensions around social isolation, use of masks, COVID-19 treatments, and mandatory vaccines, among others. As a consequence, SLB work involves regular confrontations, especially for those who respond directly to the pandemic. Examples include hostility faced by health professionals who refuse to recommend certain medications or by police officers when they demand the use of masks. For those who continue to perform their work face-to-face, even if they do not deal directly with the pandemic, these conflicts impact on how these professionals work and interact with citizens. An example is the requirement, or not, to use a mask in public transportation. Finally, for the SLB group that started to operate remotely, these conflicts may appear through public pressure to either resume on-site delivery of services or to keep them remote, as has been the case in the educational system.

Table 1, below, summarizes the difficulties experienced by SLB in exercising their functions, considering similarities and differences among the three groups analyzed, as well as the factors associated with these challenges: (i) the centralization of decision-making processes; and greater degrees of (ii) uncertainty and (iii) political conflict. 
Table 1 - SLB groups and the implications of COVID-19 for their work

\begin{tabular}{|c|c|c|c|}
\hline SLB groups: & $\begin{array}{c}\text { (i) Centralization of } \\
\text { decision-making processes: }\end{array}$ & (ii) Greater ambiguity: & (iii) Greater political conflict: \\
\hline Common aspects & $\begin{array}{l}\text { - Emergence of operational } \\
\text { bottlenecks, with disregard } \\
\text { to local specificities } \\
\text { - SLBs' partial understanding } \\
\text { of new regulations }\end{array}$ & $\begin{array}{l}\text { - Lower levels of control over } \\
\text { SLB working practices and } \\
\text { greater margin for discretion } \\
\text { (without adequate guidance) }\end{array}$ & $\begin{array}{l}\text { - Hinders everyday } \\
\text { implementation and } \\
\text { interaction with the public } \\
\text {-SLB can propagate conflicts } \\
\text { that directly or indirectly } \\
\text { affect pandemic response }\end{array}$ \\
\hline $\begin{array}{l}\text { 1-SLBs who act on the front } \\
\text { line in combating COVID-19 } \\
\text { (Ex.: healthcare, social } \\
\text { assistance, public security) }\end{array}$ & $\begin{array}{l}\text { - Less capacity to respond } \\
\text { to the pandemic, as specific } \\
\text { actions for certain locations and } \\
\text { communities are disregarded }\end{array}$ & $\begin{array}{l}\text { - Lack of clear protocols } \\
\text { to guide SLB in respon- } \\
\text { ding to the crisis } \\
\text { - Reduced SLB capacity to } \\
\text { act in the face of the crisis }\end{array}$ & $\begin{array}{l}\text {-SLBs, when facing the pande- } \\
\text { mic, interact with individuals } \\
\text { with different political positions }\end{array}$ \\
\hline $\begin{array}{l}\text { 2-SLBs who work face- } \\
\text {-to-face but do not directly } \\
\text { respond to the pandemic } \\
\text { (Ex.:publictransportation, } \\
\text { street cleaning) }\end{array}$ & $\begin{array}{l}\text { - Unforeseen situations } \\
\text { expose SLBs and the public } \\
\text { to risk of infection }\end{array}$ & $\begin{array}{l}\text { - Lack of regulation for } \\
\text { face-to-face work and } \\
\text { operational bottlenecks }\end{array}$ & $\begin{array}{l}\text { - SLBs deliver their services } \\
\text { to citizens who position } \\
\text { themselves differently in relation } \\
\text { to the pandemic (e.g., on } \\
\text { the question of mandatory } \\
\text { mask use in public spaces) }\end{array}$ \\
\hline $\begin{array}{l}\text { 3-SLBs who have } \\
\text { migrated to remote work } \\
\text { (Ex..education, legal aid, local } \\
\text { government admin staff) }\end{array}$ & $\begin{array}{l}\text { - Greater feelings of unprepa- } \\
\text { redness among SLBs to carry } \\
\text { out new activities remotely }\end{array}$ & $\begin{array}{l}\text { - Lack of training and adequate } \\
\text { transition to remote working } \\
\text { - Difficulty in serving the } \\
\text { most vulnerable groups }\end{array}$ & $\begin{array}{l}\text {-SLB faces pressure over whether } \\
\text { to resume face-to-face delivery of } \\
\text { services or to keep them remote }\end{array}$ \\
\hline
\end{tabular}

\section{Final considerations}

The COVID-19 pandemic has caused a deep crisis in Brazil, demanding answers from the state to difficult questions that inevitably affect the activities of SLB. In this context, we seek to analyze what these frontline professionals have been feeling during the crisis, what has changed in their work and how these changes have affected the provision of public services and the guarantee of rights to the population.

Based on the results, this article proposes a typology of SLB activities in the midst of the pandemic, which can be extended to other crisis situations: (i) services that remain in person and are aimed at responding directly to the crisis or its consequences; (ii) services that remain in person but do not respond directly to the crisis; 
(iii) services that migrated to remote work due to the limitations imposed by the pandemic.

These new social conditions have exacerbated the problems already faced by these professionals in their day-to-day work, such as large distances between different bureaucratic levels and deficiencies in intergovernmental coordination. Furthermore, the health crisis increased inequalities that already exist in the country. As the humanitarian disasters rooted in our deeply unequal society gained visibility during the COVID-19 pandemic, governments came under pressure to come up with responses, which did not always fit with the reality faced in the work of SLB.

Based on the literature, our data suggest that three factors have altered the working practices of these professionals in the context of the crisis: greater centralization in the formulation of responses, leading to regulatory frameworks that do not correspond to the everyday practices of SLBs and do not incorporate their prior knowledge; the rupture of the (both formal and informal) systems that governed the discretion of these professionals, leading to an increasingly ambiguous and contradictory context, in which the SLB actions might place the public at risk; and, finally, the intensification of political conflict that both affects SLB in their efforts to deliver services to citizens and is propagated by it, since no sector is made up of professionals who all think alike.

Although these three factors have changed the everyday work of SLB, it is possible to highlight some specificities between the groups studied in this article. In the case of those working on the front line to combat the pandemic, centralization of decision-making and high ambiguity and conflict not only hindered the implementation of policies, but also made it impossible to incorporate solutions that took into account the needs of communities and service users. With regard to those who maintained in person activities but did not work directly in responding to the pandemic, these factors are reflected in the low level of regulation of their work, causing greater risk of infection for both the SLBs and those using these services. Finally, among the SLBs that started to work remotely, 
their exclusion from decision-making processes and the increased levels of conflict and ambiguity hampered the process of transition and reorganization of services to remote formats, which occurred over a short period of time without the proper support. The digital divide, in the context of crisis, also further exacerbated the inequalities that already existed in the delivery of public policies.

The crisis arising from the COVID-19 pandemic presents an opportunity to rethink the formulation of public policies in a broader way, with the participation of various actors involved in the delivery of these services to citizens. It also encourages reflection on how to construct bureaucracies that are capable of adapting procedures, methods and even the scope of work to the specific demands of emergency situations, so that they are able to use situational knowledge in the face of crises (GOFEN; LOTTA, 2021).

There is thus ample space for developing research on how to overcome the crisis we are experiencing in the midst of the COVID-19 pandemic in Brazil, and on strengthening the state's capacity to deal with future crises. Future research should also deepen the analysis of coping strategies adopted by different bureaucrats in the crisis context - for example, how teachers dealt with the issue of approval (or not) at the end of the 2020 school year. We highlight the importance of analyzing this reality from the perspective of street-level bureaucracy, which is crucial for understanding the dynamics of how the state, and society as a whole, function. Such research has the potential to contribute directly to improving the design and implementation of public policies, by revealing everyday processes that directly affect the delivery of public services and, consequently, the results of state action for the population.

\section{References}

ABRUCIO, Fernando et al. Combate à Covid-19 sob o federalismo bolsonarista : um caso de descoordenação intergovernamental. Revista de Administração Pública, Rio de Janeiro, v. 54, n. 4, p. 663-677, 2020. DOI 10.1590/0034-761220200354. 
ALCADIPANI, Rafael et al. Street-level bureaucrats under Covid-19: police officers' responses in constrained settings. Administrative Theory and Praxis, Armonk, v. 42, n. 3, p. 394-403, 2020. DOI 10.1080/10841806.2020.1771906.

ARAGÃO, Érica. Em 3 meses, quase triplica número de mortes de enfermeiros no Brasil do descaso. Central Única dos Trabalhadores, [Online], 2020. Available at: https://www.cut. org.br/noticias/em-3-meses-quase-triplica-numero-de-mortesde-enfermeiros-no-brasil-do-descaso-f1cb. Accessed on: 22 September 2020.

ARNOLD, Gwen. Distinguishing the street-level policy entrepreneur. Public Administration, Oxford, p. 1-34, 2020. DOI 10.1111/padm.12703.

ARRETCHE, Marta. Democracia, federalismo e centralização no Brasil. São Paulo: Editora FioCruz; Editora FGV, 2012.

BALBE, Ronald da Silva. Uso de tecnologias de informação e comunicação na gestão pública: exemplos no governo federal. Revista do Serviço Público, Brasília, v. 61, n. 2, p. 189-209, 2010. DOI 10.21874/rsp.v61i2.45.

BARDIN, Laurence. Análise de conteúdo. Lisboa: Edições 70, 1994.

BAZANI, Adamo. Sistema de ônibus de São Paulo tem 246 funcionários confirmados com Covid-19 e 68 mortos. Diário do Transporte, São Paulo, 2020. Available at: https:// diariodotransporte.com.br/2020/08/18/sistema-de-onibus-desao-paulo-tem-246-funcionarios-confirmados-com-covid-19e-68-mortos/. Accessed on : 10 September. 2020.

BECK, Amanda Lui; BARTOS, Mariana Scaff Haddad; LOTTA, Gabriela. Só a saúde resolve? A urgência de ações intersetoriais na crise do Covid-19. Estado de São Paulo, São Paulo, May $3^{\text {rd }}$, 2020. Blog Gestão, Política \& Sociedade. Available at: https:// politica.estadao.com.br/blogs/gestao-politica-e-sociedade/so-asaude-resolve-a-urgencia-de-acoes-intersetoriais-na-crise-docovid-19/. Accessed on: May $4^{\text {th }}, 2020$. 
BENEDITO, Beatriz Soares et al. E quem não tem casa? Estado de São Paulo, São Paulo, 21 jul. 2020. Blog Gestão, Política \& Sociedade. Available at: https://politica.estadao.com.br/blogs/ gestao-politica-e-sociedade/e-quem-nao-tem-casa/. Accessed on: July $22^{\text {nd }}, 2020$.

BOIN, Arjen; 'T HART, Paul. Public leadership in times of crisis: mission impossible? Public Administration Review, Washington, D. C., v. 63, n. 5, p. 544-553, 2003. DOI 10.1111/1540-6210.00318.

BRASIL. Lei n. 13.982. Altera a Lei no 8.742, de 7 de dezembro de 1993, para dispor sobre parâmetros adicionais de caracterização da situação de vulnerabilidade social para fins de elegibilidade ao benefício de prestação continuada (BPC), e estabelece medidas excepcionais de proteção social a serem adotadas durante o período de enfrentamento da emergência de saúde pública de importância internacional decorrente do coronavírus (Covid19) responsável pelo surto de 2019 , a que se refere a Lei $n^{\circ}$ 13.979, de 6 de fevereiro de 2020. Diário Oficial da União, Brasília, DF, ano CLVIII, n. 64-A, Seção 1, 2 abr. 2020. Available at: https://pesquisa.in.gov.br/imprensa/jsp/visualiza/index. jsp?data $=02 / 04 / 2020 \&$ jornal $=600 \&$ pagina $=1$. Acessed on: July $05^{\text {th }}, 2020$.

BRODKIN, Evelyn Z. Reflections on street-level bureaucracy: past, present, and future. Public Administration Review, Washington, D. C., v. 72, n. 6, p. 940-949, 2012. DOI 10.111/j.1540-6210.2012.02657.x.Book.

BRODKIN, Evelyn Z. street-level organizations at the front lines of crises. Journal of Comparative Policy Analysis: Research and Practice, [Online], p. 1-14, 2021. DOI 10.1080/13876988.2020.1848352.

BRYMAN, Alan. Social research methods. 5. ed. Oxford: Oxford University Press , 2016. 
CEPEDISA; CONECTAS DIREITOS HUMANOS. Direitos na pandemia. Mapeamento e análise das normas jurídicas de resposta à Covid-19 no Brasil. Boletim, São Paulo, n. 09, p. 1-15, Nov 26 ${ }^{\text {th }}$, 2020.Available at: https://www.conectas.org/wp/ wp-content/uploads/2020/11/09boletimcovid_07.pdf. Accessed on: Dec $05^{\text {th }}, 2020$.

CORTEZ, Ana et al. O colapso pela morte: o sistema prisional na pandemia. Estado de São Paulo, São Paulo, May 07 ${ }^{\text {th }}, 2020$. Blog Gestão, Política \& Sociedade. Available at: https://politica. estadao.com.br/blogs/gestao-politica-e-sociedade/o-colapsopela-morte-o-sistema-prisional-na-pandemia/. Accessed on: May $08^{\text {th }}, 2020$.

COSTA, Marco Aurélio et al. Nota Técnica 15(Dirur): apontamentos sobre a dimensão territorial da pandemia da Covid-19 e os fatores que contribuem para aumentar a vulnerabilidade socioespacial nas unidades de desenvolvimento humano de áreas metropolitanas brasileiras. Brasília: Ipea, abr. 2020. Available at: https://www.ipea.gov.br/portal/index.php?option =com content $\&$ view $=$ article\&id $=35497 \&$ catid $=3 \&$ Itemid $=3$. Accessed on: August $15^{\text {th }}, 2020$.

COSTA, Sérgio. Desigualdades, interdependência e políticas sociais no Brasil. In: PIRES, Roberto Rocha Coelho (org.). Implementando desigualdades: reprodução de desigualdades na implementação de políticas públicas. Rio de Janeiro: Ipea, 2019. p. 53-77. Available at: https://www.ipea.gov.br/portal/ index.php? option=com_content $\&$ view $=$ article $\&$ id $=34743$. Accessed on: October 01 ${ }^{\text {st }}, 2020$.

COX, Roberty Henry; DICKSON, Daniel; MARIER, Patrik. Resistance, innovation, and improvisation: comparing the responses of nursing home workers to the Covid-19 pandemic in Canada and the United States. Journal of Comparative Policy Analysis: Research and Practice, [Online], p. 1-11, 2021. DOI 10.1080/13876988.2020.1846994. 
CRESWELL, John W. Qualitative inquiry and research design: choosing among five approaches. Thousand Oaks, California: SAGE Publications, 2013.

CRISTÓVAM, JoséSérgio da Silva; SAIKALI, Lucas Bossoni; SOUSA, Thanderson Pereira de. Governo digital na implementação de serviços públicos para a concretização de direitos sociais no Brasil. Sequiência: Estudos Jurídicos e Políticos, [Online], v. 43, n. 84, p. 209-242, 2020. DOI 10.5007/2177-7055.2020v43n89p209.

DE FELICE, Fernanda G. et al. Severe Acute Respiratory Syndrome Coronavirus 2 (SARS-CoV-2) and the central nervous system. Trends in Neurosciences, [Online], v. 43, n. 6, p. 355-357, 2020. DOI 10.1016/j.tins.2020.04.004.

DUBOIS, Vicent. La vie au guichet. Relation administrative et traitement de la misère. 3. ed. Paris: Economica, 1999. (Collection Études Politiques).

DUNLOP, Adrian et al. Challenges in maintaining treatment services for people who use drugs during the Covid-19 pandemic. Harm Reduction Journal, [Online] v. 17, n. 1, p. 1-7, 2020. DOI 10.1186/s12954-020-00370-7.

FARAZMAND, Ali. Learning from the Katrina crisis: a global and international perspective with implications for future crisis management. Public Administration Review, Washington, D. C., v. 67, p. 149159, 2007. DOI 10.4324/9781315095264.

FERNANDEZ, Michelle Vieira; GUIMARÃES, Natália Cordeiro. Caminhos teórico-metodológicos para a análise da burocracia de nível de rua. Revista Brasileira de Ciência Política, Brasília, n. 32, p. 283-322, 2020. DOI 10.1590/0103-335220203208.

FRISCH AVIRAM, Neomi; COHEN, Nissim; BEERI, Itai. Wind(ow) of change: a systematic review of policy entrepreneurship characteristics and strategies. Policy Studies Journal, [S. l.], v. 48, n. 3, p. 612-644, 2020. DOI 10.1111/psj.12339. 
GOFEN, Anat; LOTTA, Gabriela. Street-level bureaucrats at the forefront of pandemic response : a comparative perspective street-level. Journal of Comparative Policy Analysis: Research and Practice, [Online], p. 1-13, 2021. DOI $10.1080 / 13876988.2020 .1861421$.

HENDERSON, Alexander C. The critical role of street-level bureaucrats in disaster and crisis. In: SCHWESTER, Richard (ed.). Handbook of critical incident analysis. New York \& Oxon: Routledge, 2014. p. 210-245.

HILL, Heather C. Mathematical knowledge of middle school teachers: implications for the no child left behind policy initiative. Educational Evaluation and Policy Analysis, Washington, D. C., v. 29, n. 2, p. 95-114, 2007. DOI 10.3102/0162373707301711. IBGE - Instituto Brasileiro de Geografia e Estatística. Pesquisa Nacional por Amostra de Domicílios Contínua Primeiro Trimestre de 2020. Brasília: IBGE, 2020. Available at: https://biblioteca.ibge.gov.br/visualizacao/periodicos/2421/ pnact_2020_1tri.pdf. Accessed on: June 11 ${ }^{\text {th }}, 2020$.

INSTITUTO PENÍNSULA. Sentimento e percepção dos professores brasileiros nos diferentes estágios do Coronavírus no Brasil. São Paulo: Instituto Península, mar. 2020. Available at: https://institutopeninsula.org.br/wp-content/uploads/2020/05/ Pulso-Covid-19_-Instituto-Pen\%C3\%ADnsula.pdf. Accessed on: September $09^{\text {th }}, 2020$.

KHANAL, Pratik et al. Mental health impacts among health workers during Covid-19 in a low resource setting: a cross-sectional survey from Nepal. Globalization and Health, [Online], v. 16, n. 1, p. 1-12, 2020. DOI 10.1186/s12992-020-00621-z.

KLASSMANN, Bruna. Trabalho escravo: 231 trabalhadores foram resgatados no primeiro semestre de 2020. Revista Proteção, Novo Hamburgo, 23 jul. 2020. Available at: https://protecao.com. $\mathrm{br} /$ geral/trabalho-escravo-231-trabalhadores-foram-resgatadosno-primeiro-semestre-de-2020/. Accessed on: August 07 ${ }^{\text {th }}, 2020$. 
KRIEGER, Morgana G. Martins et al. Desigualdade urbana e redes de solidariedade: as periferias e favelas no enfrentamento à pandemia. Estado de São Paulo, São Paulo, 25 maio 2020. Blog Gestão, Política \& Sociedade. Available at: https:// politica.estadao.com.br/blogs/gestao-politica-e-sociedade/ desigualdade-urbana-e-redes-de-solidariedade-as-periferias-efavelas-no-enfrentamento-a-pandemia/. Accessed on: May $26^{\text {th }}$, 2020.

LAI, Jianbo et al. Factors associated with mental health outcomes among health care workers exposed to coronavirus disease 2019. JAMA Network Open, [Online], v. 3, n. 3, p. 1-12, 2020. DOI 10.1001/jamanetworkopen.2020.3976.

LAVEE, Einat; COHEN, Nissim. How street-level bureaucrats become policy entrepreneurs: the case of urban renewal. Governance, Oxford, v. 32, n. 3, p. 475-492, 2019. DOI 10.1111/ gove.12387.

LIMA, Carlos Eduardo; LOTTA, Gabriela. Sem home office para os servidores da linha de frente: o trabalho nas prisões em tempos. Estado de São Paulo, São Paulo, 18 maio 2020. Blog Gestão, Política \& Sociedade. Available at: https://politica.estadao.com. br/blogs/gestao-politica-e-sociedade/sem-home-office-paraos-servidores-da-linha-de-frente-o-trabalho-nas-prisoes-emtempos-de-pandemia/. Accessed on: May 19 ${ }^{\text {th }}, 2020$.

LIMA, Débora Dossiatti de et al. Ocupações, cortiços e a pandemia: entre a criminalização e a solidariedade. Estado de São Paulo, São Paulo, 29 jun. 2020. Blog Gestão, Política \& Sociedade. Available at: https://politica.estadao.com.br/blogs/gestaopolitica-e-sociedade/ocupacoes-corticos-e-a-pandemia-entrea-criminalizacao-e-a-solidariedade/. Accessed on: June $19^{\text {th }}$, 2020.

LIPSKY, Michael. Street-level bureaucracy: dilemmas of the individual in public service. 3. ed. New York: Russell Sage Foundation, 2010.

LOTTA, Gabriela. Teorias e análises sobre implementação de políticas públicas no Brasil. Brasília: Enap, 2019. 
LOTTA, Gabriela; COELHO, Vera Schattan Ruas Pereira; BRAGE, Eugenia. How Covid-19 has affected frontline workers in Brazil: a comparative analysis of nurses and community health workers. Journal of Comparative Policy Analysis: Research and Practice, [Online], p. 1-11, 2020. DOI 10.1080/13876988.2020.1834857.

LOTTA, Gabriela et al. Community health workers reveal Covid-19 disaster in Brazil. The Lancet, [Online], v. 396, n. 10248, p. 365-366, 2020. DOI 10.1016/S0140-6736(20)31521-X.

LOTTA, Gabriela; SANTIAGO, Ariadne. Autonomia e discricionariedade: matizando conceitos-chave para o estudo de burocracia. Revista Brasileira de Informação Bibliográfica em Ciências Sociais - BIB, São Paulo, v. 83, p. 21--42, 2017.

MATLAND, Richard E. Synthesizing the implementation literature: the ambiguity-conflict model of policy implementation. Journal of Public Administration Research and Theory, Oxford, v. 5, n. 2, p. 145-174, 1995. DOI 10.1093/oxfordjournals.jpart.a037242. MÁXIMO, Wellton. Cerca de 12,4 milhões devem refazer cadastro no auxílio emergencial. Agência Brasil - EBC, Brasília, 4 maio 2020. Available at: https://agenciabrasil.ebc.com.br/economia/ noticia/2020-05/cerca-de-124-milhoes-devem-refazercadastro-no-auxilio-emergencial. Accessed on: July 10 ${ }^{\text {th }}, 2020$.

MAY, Peter J.; WINTER, Søren C. Politicians, managers, and streetlevel bureaucrats: Influences on policy implementation. Journal of Public Administration Research and Theory, Oxford, v. 19, n. 3, p. 453-476, 2009. DOI 10.1093/jopart/mum030.

MAYNARD-MOODY, Steven; MUSHENO, Michael. Cops, teachers, councelors: stores from the front lines of public service. Michigan: University of Michigan Press, 2003. DOI 10.3998/mpub.11924.

MAYNARD-MOODY, Steven; MUSHENO, Michael. Social equities and inequities in practice: street-level workers as agents and pragmatists. Public Administration Review, Washington, D. C., v. 72, p. 16-23, 2012. Supl. 1. DOI 10.1111/j.1540-6210.2012.02633.x. 
MØLLER, Marie Østergaard. The dilemma between selfprotection and service provision under Danish Covid-19 guidelines: a comparison of public servants' experiences in the pandemic frontline. Journal of Comparative Policy Analysis: Research and Practice, [Online], p. 1-15, 2020. DOI 10.1080/13876988.2020.1858281.

NUNES, Ana Carolina et al. Direitos não entram em quarentena: é preciso atenção às mulheres em risco. Estado de São Paulo, São Paulo, 21 maio 2020. Blog Gestão, Política \& Sociedade. Available at: https://politica.estadao.com.br/blogs/gestaopolitica-e-sociedade/direitos-nao-entram-em-quarentena-epreciso-atencao-as-mulheres-em-risco/. Accessed on: May 22 ${ }^{\text {nd }}$, 2020.

PIRES, Roberto Rocha Coelho. Estilos de implementação e resultados de políticas públicas: fiscais do trabalho e o cumprimento da lei trabalhista no Brasil. DADOS - Revista de Ciências Sociais, Rio de Janeiro, v. 52, n. 3, p. 735-769, 2009. DOI 10.1590/s0011-52582009000300006.

PIRES, Roberto Rocha Coelho. Implementando desigualdades: reprodução de desigualdades na implementação de políticas públicas. Brasília: Ipea, 2019.

PIRES, Roberto Rocha Coelho. Nota Técnica n. 33 (Diest): os efeitos sobre grupos sociais e territórios vulnerabilizados das medidas de enfrentamento à crise sanitária da Covid-19: propostas para o aperfeiçoamento da ação pública. Brasília: Ipea, abr. 2020. Available at: https://www.ipea.gov.br/portal/images/stories/ PDFs/nota_tecnica/200408_nota_tenica_diest.pdf. Accessed on: May 29 $9^{\text {th }}, 2020$.

PRESSMAN, Jeffrey L.; WILDAVSKY, Aaron. Implementation. Berkeley: University of California Press, 1995.

SALDAÑA, Johnny. The coding manual for qualitative researchers. Thousand Oaks, California: SAGE Publications , 2009. 
SANTOS, Alexsandro et al. CPFs negros importam? Racismo estrutural e políticas públicas no contexto da Covid-19. Estado de São Paulo, São Paulo, 11 maio 2020. Blog Gestão, Política \& Sociedade. Available at: https://politica.estadao.com.br/blogs/ gestao-politica-e-sociedade/cpfs-negros-importam-racismoestrutural-e-politicas-publicas-no-contexto-da-covid-19/. Accessed on: May 12 $2^{\text {th }}, 2020$.

SÃO PAULO. Decreto n. 59.384. Determina a obrigatoriedade do uso de máscaras de proteção facial no âmbito do serviço de transporte municipal de passageiros. Diário Oficial Cidade de São Paulo, São Paulo, SP, ano 65, n. 80, 30 abr. 2020. Available at: http://legislacao.prefeitura.sp.gov.br/leis/decreto-59384-de-29de-abril-de-2020. Accessed on: May 11 ${ }^{\text {th }}, 2020$.

SEQUEIRA, Ítalo Barbosa Lima ; BIONDI, Karina; GODOI, Rafael. Los efectos del coronavirus en las cárceles de Latino América. SOCLA; CELIV, jun. 2020. Available at: https://ponte.org/ wp-content/uploads/2020/07/Brasil-Informe-Regional-Efectosde-Covid19-en-cárceles-Lat_brasil.pdf. Accessed on: September $01^{\text {st }}, 2020$.

SORJ, Bernardo; GUEDES, Luís Eduardo. Exclusão digital: problemas conceituais, evidências empíricas e políticas públicas. Novos Estudos - CEBRAP, [Online], n. 72, p. 101-117, 2005. TAVARES, Amarílis Busch; SILVEIRA, Fabrício; PAES-SOUSA, Rômulo. Proteção social e Covid-19: a resposta do Brasil e das maiores economias da América Latina. Revista NAU Social, Salvador, v. 11, n. 20, p. 111-129, 2020. DOI 10.9771/ ns.v11i20.36599.

TUMMERS, Lars. The relationship between coping and job performance. Journal of Public Administration Research and Theory, Oxford, v. 27, n. 1, p. 150-162, 2017. DOI 10.1093/ jopart/muw058. 
TUMMERS, Lars; KRUYEN, Peter M.; VIJVERBERG, Dominique M.; VOESENEK, Tessa J. Connecting HRM and change management: the importance of proactivity and vitality. Journal of Organizational Change Management, Bradford, v. 28, n. 4, p. 627-640, 2015. DOI 10.1108/JOCM-11-2013-0220.

VAN OORSCHOT, Wim. Making the difference in social Europe: deservingness perceptions among citizens of European welfare states. Journal of European Social Policy, London, v. 16, n. 1, p. 23-42, 2006. DOI 10.1177/0958928706059829.

\section{Abstract}

Dealing with the Covid-19 pandemic requires that the State make hard decisions that involve the action of bureaucrats who interact with the population through the implementation of public policy, the street-level bureaucracy (SLB). In this paper, based on a mixed- method exploratory study, we analyze how the daily performance of street-level bureaucrats in different policy areas- health and social care, access to the justice system, public security and education - has changed during the pandemic. We also explore the repercussions of those changes. Based on the analysis of the perceptions of bureaucrats, changes in their work and in their relationship with the public, we identify three categories that illustrate the dynamics of SLB work during the pandemic: the SLB who faces the crisis on the front lines; the SLB who suffers the effects of the pandemic, but whose work does not require her to face it directly; and the SLB who began to work remotely. We conclude that, during the pandemic, SLB suffered in varying degrees an aggravation of structural problems, such as their removal from decision-making processes - now restricted to the highest government level - and the exacerbation of already existing conflicts and ambiguities.

Keywords: Pandemic. Street-level bureaucrats. Public policies. Ambiguity.

Received on June 13, 2020

Accepted on September 15, 2020 